\title{
Early Holocene climate oscillations recorded in three Greenland ice cores
}

Rasmussen, Sune Olander; Vinther, Bo Møllesøe; Clausen, Henrik Brink; Andersen, Katrine K.

Published in:

Quaternary Science Reviews

Publication date:

2007

Document version

Early version, also known as pre-print

Citation for published version (APA):

Rasmussen, S. O., Vinther, B. M., Clausen, H. B., \& Andersen, K. K. (2007). Early Holocene climate oscillations recorded in three Greenland ice cores. Quaternary Science Reviews, 26(15-16), 1907-1914. 


\title{
Early Holocene climate oscillations recorded in three Greenland ice cores
}

\author{
S. O. Rasmussen ${ }^{1}$, B. M. Vinther, H. B. Clausen, \\ K. K. Andersen \\ Centre for Ice and Climate, Niels Bohr Institute, University of Copenhagen, \\ Juliane Maries Vej 30, DK-2100 Copenhagen, Denmark. \\ Received 10 April 2006; accepted 19 October 2006, published 18 September $200 \%$. \\ Manuscript published in Quaternary Science Reviews, vol. 26, 2007, \\ pp. 190\%-1914, doi:10.1016/j.quascirev.200\%.06.015.
}

\begin{abstract}
A new ice core chronology for the Greenland DYE-3, GRIP, and NGRIP ice cores has been constructed, making it possible to compare the $\delta^{18} \mathrm{O}$ and accumulation signals recorded in the three cores on an almost annual scale throughout the Holocene. We here introduce the new time scale and investigate $\delta^{18} \mathrm{O}$ and accumulation anomalies that are common to the three cores in the Early Holocene (7.9-11.7 ka before present). Three time periods with significant and synchronous anomalies in the $\delta^{18} \mathrm{O}$ and accumulation signals stand out: the well known 8.2 ka event, an event of shorter duration but of almost similar amplitude around 9.3 ka before present, and the Preboreal Oscillation during the first centuries of the Holocene. For each of these sections, we present a $\delta^{18} \mathrm{O}$ anomaly curve and a common accumulation signal that represents regional changes in the accumulation rate over the Greenland ice cap.
\end{abstract}

Key words: Early Holocene, GICC05, 8.2 ka event, 9.3 ka event, Preboreal Oscillation

\section{Introduction}

The study of Early Holocene climate variations has received much attention recently. The large amount of data collected and reviewed by Alley and Ágústdóttir (2005),

$\overline{1}$ Corresponding author, olander@gfy.ku.dk, Phone +4535320590 
Rohling and Pälike (2005), and Wiersma and Renssen (2006) clearly shows that the 8.2 ka event stands out in most North Atlantic Early Holocene climate records as the most prominent climate anomaly. The $8.2 \mathrm{ka}$ event has been the subject of numerous investigations (e.g. Alley et al., 1997a, and the references above) since it was first pointed out in the Camp Century and DYE-3 $\delta^{18} \mathrm{O}$ profiles by Hammer et al. (1986), and a detailed study of the ice core evidence has just been performed by Thomas et al. (2007). In recent years, the possible connection of the event with a massive fresh water pulse (Barber et al., 1999) has motivated further studies, because the 8.2 ka event provides a unique testing ground for climate models investigating the relationship between fresh water influx to the North Atlantic and the thermohaline circulation (Renssen et al., 2001; Wiersma and Renssen, 2006). Even though most attention has been directed to the 8.2 ka event, also other anomalies are present in the Early Holocene climate proxies from the Central Greenland ice cores. Bond et al. (1997), von Grafenstein et al. (1999), and McDermott et al. (2001) all found a cold event in the time interval 9.2-9.5 ka before present, and the first centuries of the Holocene are dominated by the Preboreal Oscillation (Björck et al., 1997). Here we present the isotope and annual layer thickness profiles of the DYE-3, GRIP and NGRIP ice cores (Dansgaard et al., 1982; Johnsen et al., 1997, 2001; NGRIP members, 2004) on the new Greenland Ice Core Chronology 2005 time scale (GICC05) of Rasmussen et al. (2006). Because the GICC05 time scale is common to the three ice cores, and the synchronization of the cores is precise down to a couple of years throughout the Holocene, the data from the three cores can be compared on an almost annual scale. From these profiles, the 8.2 ka event, the 9.3 ka event and the Preboreal Oscillation are identified as the only Early Holocene climate events on decadal scale that are common to all three cores and show both a significant $\delta^{18} \mathrm{O}$ and annual layer thickness anomaly.

\section{The Greenland Ice Core Chronology 2005}

As a part of the Copenhagen Ice Core Dating Initiative, a new common time scale has been constructed for the DYE-3, GRIP, and NGRIP ice cores. The time scale is based on all available data series from the three ice cores that can be used to identify annual layers and has been named the Greenland Ice Core Chronology 2005 (GICC05). The construction of the GICC05 down to 7.9 ka before present is described in detail by Vinther et al. (2006), while the dating of the part from $7.9 \mathrm{ka}$ before present to and including the Greenland Interstadial 1 (GI-1) is described by Rasmussen et al. (2006). The result of this dating effort will be summarized here. It should be noted that the GICC05 time scale reports ages relative to the year A.D. 2000, and that the notation b2k has been adapted to avoid confusion with the BP notation that has been used both with the conventional A.D. 1950 base year and other non-conventional base years when reporting ice core results. Also, it should be noted that the so-called maximum counting errors reported below are conserva- 
tive estimates of the maximum error due to interpretation of ambiguous features in the data set, and not the total uncertainties of the time scale. The uncertainty contribution from data gaps and annual layers that have been removed from the sequence due to wind scouring or other post-depositional effects are negligible in the Holocene, but the criteria used for identifying the annual layers may be incorrect, introducing a possible bias in the dating.

In the upper section, the time scale has been constructed using stable isotope ratios. The advantage is that the $\delta^{18} \mathrm{O}$ and $\delta \mathrm{D}$ profiles exhibit a clear annual cycle that allows reliable identification of annual layers, especially when several cores are dated in parallel. The individual profiles are matched using Electrical Conductivity Measurement (ECM) data that provide good match-points between the different profiles every 30-50 years on average. For the most recent $2 \mathrm{ka}$, annual layers have been identified using $\delta^{18} \mathrm{O}$ data from DYE-3, GRIP, NGRIP, and a few additional shallow cores, and the time scale is considered to be exact at the volcanic layer of Vesuvius (A.D. 79), which has been unambiguously identified from the tephras found in the ice core. In the $2-3.8 \mathrm{ka} \mathrm{b} 2 \mathrm{k}$ section, $\delta^{18} \mathrm{O}$ data from the GRIP and DYE-3 cores resolve the annual layers well, and the annual layers were identified from the combined matched records. The reproducibility of the annual layer count is very good, and the maximum counting error is estimated to be around $0.25 \%$, corresponding to 5 years over the entire section. In the 3.8-7.9 ka b2k section the time scale is based on DYE-3 stable isotope ratios alone, and the uncertainty thus rises. In the 3.8-6.9 ka b2k part, the estimated maximum counting error is estimated to about $0.5 \%$, rising to $2 \%$ in the $6.9-7.9$ ka b2k section.

At greater depths, isotope ratios are not optimal for dating as the annual signal is obscured by progressing ice-flow-induced thinning of annual layers and diffusion smoothing, and the GICC05 time scale is therefore based on measurements of the impurity content of the ice below $7.9 \mathrm{ka} \mathrm{b} 2 \mathrm{k}$. The advantage of the impurity records is that they are not significantly affected by diffusion in the firn or ice, and are measured with high resolution. Also several parallel impurity records extracted from the same core can be used for annual layer identification, even though the annual signal can be less clear in the individual data series. ECM data and Continuous Flow Analysis (CFA) impurity records from GRIP (7.9-11.7 ka b2k section) (Fuhrer et al., 1993, 1996) and NGRIP (10.3-14.8 ka b2k section) have been used (Röthlisberger et al., 2000; Bigler, 2004). The maximum counting error is estimated to be $0.7-2 \%$ in the Holocene part and approximately $3 \%$ in the Greenland Stadial 1 (GS-1) and GI-1 periods.

The GICC05 time scale dates the termination of GS-1 (and thus the onset of the Holocene) to $11703 \mathrm{~b} 2 \mathrm{k}$ with a maximum counting error of 99 years, and the onset of GI-1e to $14692 \mathrm{~b} 2 \mathrm{k}$ with a maximum counting error of 186 years. The new GICC05 time scale agrees well with the GISP2 time scale (Meese et al., 1997; Alley et al., 1997b) at the termination of GS-1, thereby moving the transition some 150 years back relative to the existing GRIP and NGRIP time scales (Johnsen et al., 2001; NGRIP members, 2004). Although the different time scales thus agree well on the date of some of the major transitions, there are relative differences within Holocene, GS-1, and GI-1 periods of up to $7 \%$ between the number of years in the 


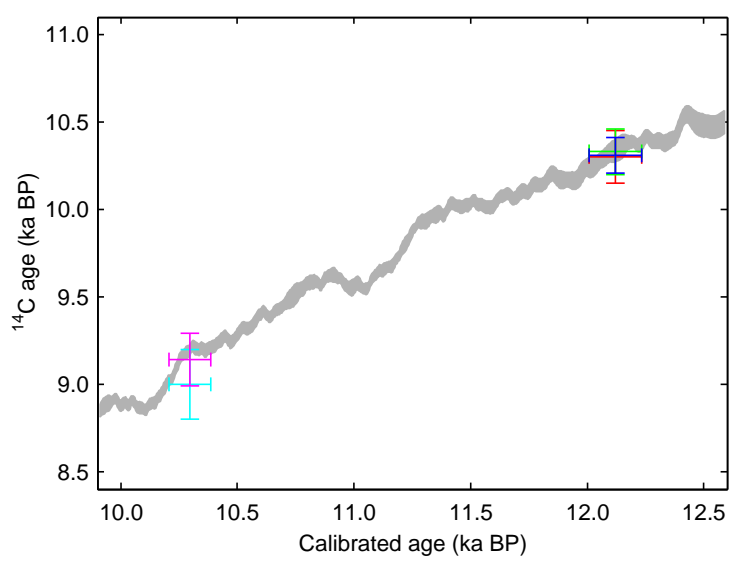

Fig. 1. By using tephra layers dated independently in the ice cores and by ${ }^{14} \mathrm{C}$ dating (crosses), the GICC05 ice core time scale can be compared with the IntCal04 terrestrial radiocarbon age calibration curve of Reimer et al. (2004), shown as the $\pm 2 \sigma$ interval in grey shade. The horizontal error bars show the maximum counting error estimates of the GICC05 and the vertical error bars show the $2 \sigma$-uncertainty estimates of the ${ }^{14} \mathrm{C}$ dates (see text for ${ }^{14} \mathrm{C}$ dates and references). The GICC05 time scale is seen to be consistent with the IntCal04 curve both at the time of the Saksunarvatn eruption (left data points) and at age of the Vedde eruption (right data points). Conventional BP ages (before 1950) are used in this figure.

GICC05, GISP2 and former GRIP/NGRIP time scales, respectively.

The GICC05 is thus constructed using different data series from the DYE-3, GRIP, and NGRIP ice cores in different sections, and patching these sections together into one consistent time scale, using at all times data from the core(s) that are optimal for that section. In this way it has also been possible to avoid basing the time scale on data from the brittle part of any of the cores. The cores have been matched throughout the Holocene so that the GICC05 here is a common time scale to the three ice cores, while the time scale in the glacial part presently is established only for the NGRIP core. In this work we focus on the Early Holocene section (7.9-11.7 ka b2k), where the time scale is based on impurity records.

Using the Saksunarvatn and Vedde tephra layers identified in the Greenland ice cores together with the corresponding ${ }^{14} \mathrm{C}$ age of the tephras, the GICC05 time scale can be directly compared with the IntCal04 terrestrial radiocarbon age calibration curve of Reimer et al. (2004). The Saksunarvatn tephra is dated to 10347 b2k according to the GICC05, while the Vedde tephra is located at $12171 \mathrm{~b} 2 \mathrm{k}$ (with maximum counting errors of 89 and 114 years, respectively). The review paper of Grönvold et al. (1995) gives two estimates of the ${ }^{14} \mathrm{C}$ age of the Saksunarvatn tephra: 9140 BP from Jóhansen (1975) with an estimated $1 \sigma$-uncertainty of 75 years (Grönvold, pers. comm.), and 8900 BP from Björck et al. (1992). The latter has been changed to $9000 \mathrm{BP}$ with an estimated uncertainty of 100 years by Björck et al. (2001). For the Vedde tephra, Bard et al. (1994) obtain 10300 BP from 5 samples from two sites bracketing the tephra. From their data we estimate the $1 \sigma$ uncertainty to be around 75 years, being well in agreement with the estimates of $10330 \pm 65$ BP from Wastegård et al. (1998) and the $10310 \pm 50$ from Birks et al. 


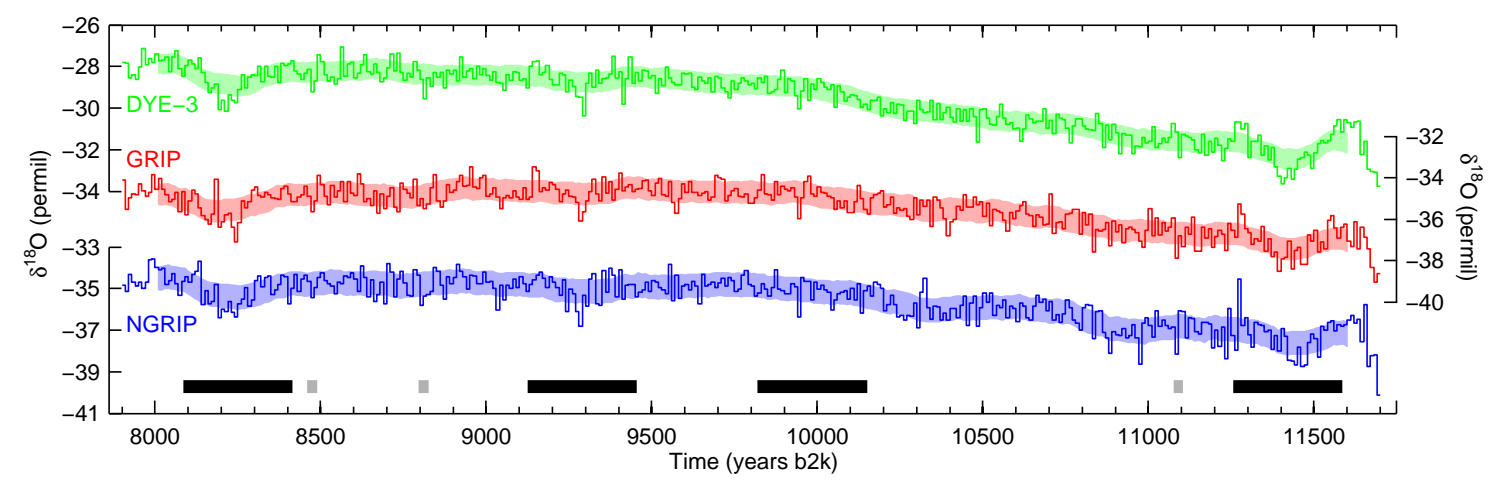

Fig. 2. The DYE-3, GRIP and NGRIP $\delta^{18} \mathrm{O}$ profiles in the $7.9-11.7 \mathrm{ka}$ b2k interval, resampled to 10 year resolution on the GICC05 time scale. The shaded envelopes are the regions that are within one standard deviation from the 210 year running mean of the individual profiles. The black lines at the bottom indicate the position of the sections shown in Fig. 4.

(1996). The GICC05 and ${ }^{14} \mathrm{C}$ ages are shown in Fig. 1 together with the IntCal04 calibration curve of Reimer et al. (2004). The error bars show the maximum counting error estimates of the GICC05 time scale and the $2 \sigma$-uncertainty estimates of the ${ }^{14} \mathrm{C}$ dates. It it seen that that the GICC05 time scale is fully consistent with the IntCal04 curve, as the different age estimates fit well within the respective error margins.

\section{The Early Holocene records}

The 7.9-11.7 ka b2k part of the $\delta^{18} \mathrm{O}$ profiles of DYE-3, GRIP, and NGRIP are shown on the GICC05 time scale in Fig. 2 as 10 year average values. It is seen that, in general, although the profiles agree on many details, there are also significant differences between the curves. As the distance between the DYE-3 and NGRIP drill sites is more than $1000 \mathrm{~km}$, it is clear that the isotope signals cannot be expected to covary on short time scales, while the profiles are expected to contain common imprints of climatic events on regional or hemispheric scales. As a simple indicator of which features in the isotope profiles are common to the three records, we look at the places where all three profiles simultaneously deviate more than one standard deviation from their respective running means. Each of the shaded bands around the isotope profiles in Fig. 2 represent plus/minus one standard deviation from the 210 year running mean. The exact choice of averaging length is arbitrary, but the value should be larger than the typical duration of the expected (decadal-scale) anomalies, and small enough for the running mean curve to capture the gradual trends observed in the 10-11.7 ka b2k section.

It is seen that the three profiles only have strong common features deviating from the $\pm 1 \sigma$ variation band at the well known 8.2 ka event, at $9.3 \mathrm{ka} \mathrm{b} 2 \mathrm{k}$, and in the 


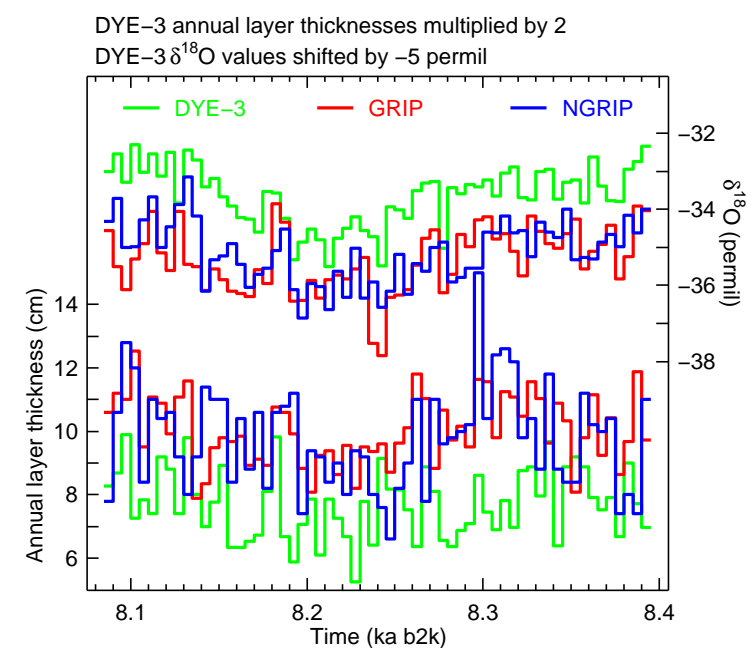

Fig. 3. Annual layer thicknesses (left axis) and $\delta^{18} \mathrm{O}$ values (right axis) from the DYE-3, GRIP, and NGRIP ice cores around the 8.2 ka event, averaged to 5 year resolution. Note that the DYE-3 curves have been shifted vertically to fit the scale. While the three $\delta^{18} \mathrm{O}$ curves agree on the overall shape of the event, the annual layer thickness profiles are less similar, and do not agree well with the shape of the $\delta^{18} \mathrm{O}$ profiles.

Preboreal oscillation at 11.4-11.5 ka b2k, while a number of smaller features occur around 8.5, 8.8, 9.95 and $11.1 \mathrm{ka} \mathrm{b2k}$. The anomalies in the $\delta^{18} \mathrm{O}$ profiles can be attributed to temperature anomalies, but also to changing moisture sources and/or transport paths (Johnsen et al., 1989; Masson-Delmotte et al., 2005), and it is likely that these changes would also lead to changes in the annual accumulation at the drill sites. To determine whether the $\delta^{18} \mathrm{O}$ anomalies are likely to represent larger scale features that are probably also observable outside Greenland, the obvious choice is to investigate whether simultaneous changes are observed in the annual layer thicknesses, reflecting changes in the amount of precipitation. The $\delta^{18} \mathrm{O}$ profiles and the annual layer thickness profiles from the DYE-3, GRIP and NGRIP cores around the 8.2 ka event are shown in Fig. 3 averaged to 5 year resolution (note that the DYE-3 profiles have been shifted vertically to ease the comparison). It is seen that the annual layer thickness profiles have a negative anomaly coinciding with the $\delta^{18} \mathrm{O}$ minimum, although the anomaly appears to have a longer duration and smaller amplitude in the DYE-3 profile. However it is clear that the amplitude of the common anomaly is comparable to, or smaller than, the amplitude of the short term variations in the individual annual layer thickness series. Although the $\delta^{18} \mathrm{O}$ profiles agree better on the shape and amplitude of the anomaly than the accumulation profiles, significant differences can be found e.g. in the exact timing and amplitude of the deepest $\delta^{18} \mathrm{O}$ minimum. 


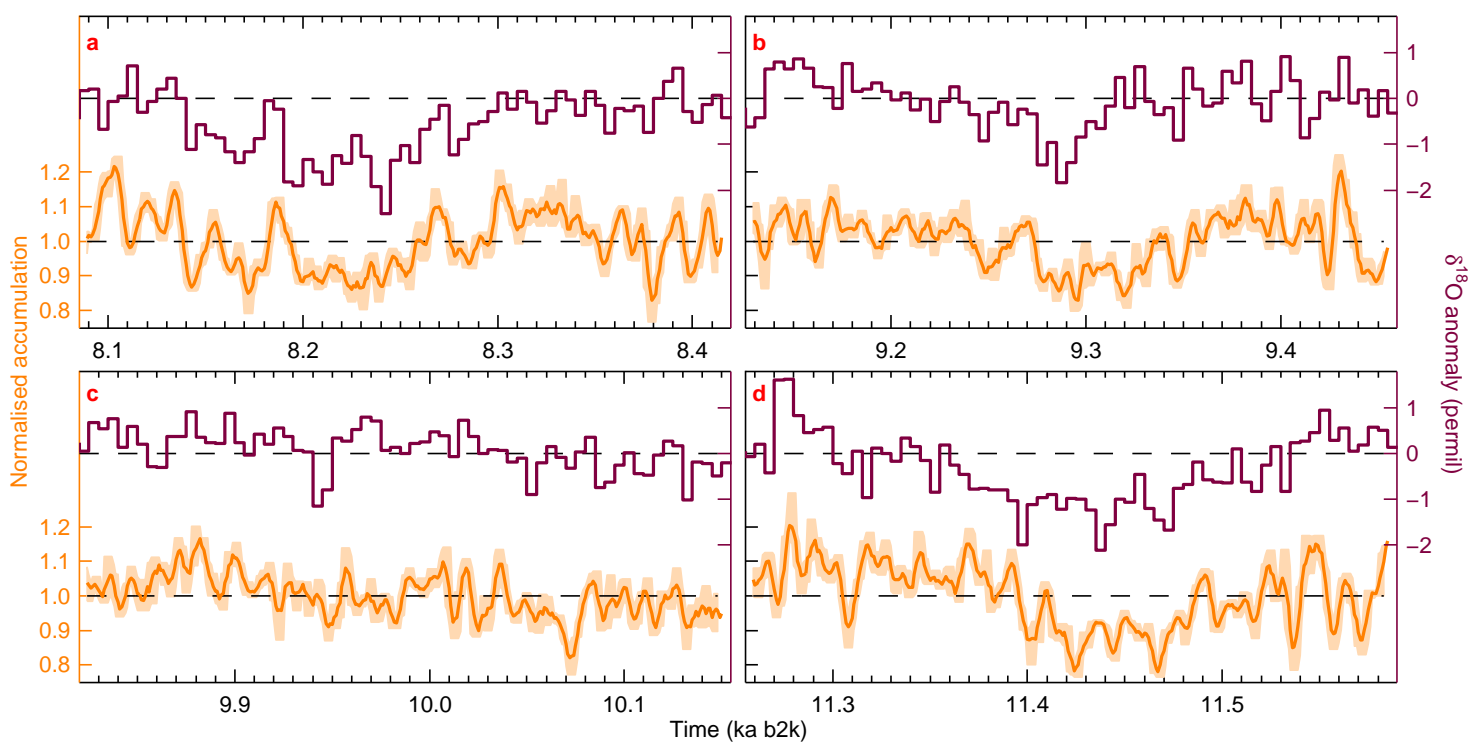

Fig. 4. Modelled accumulation rates and mean $\delta^{18} \mathrm{O}$ curves across the 8.2 ka event (a, top left), the $9.3 \mathrm{ka}$ event (b, top right), the $9.95 \mathrm{ka} \delta^{18} \mathrm{O}$ anomaly (c, bottom left) and the Preboreal Oscillation ( $\mathrm{d}$, bottom right). The shaded bands indicate the uncertainty intrinsic to the accumulation model. For further explanation, refer to section 4 .

\section{Characterization of the Early Holocene climate events}

Because of the differences between the individual accumulation and $\delta^{18} \mathrm{O}$ profiles, we aim at producing a single accumulation and $\delta^{18} \mathrm{O}$ anomaly curve that characterizes the general Greenland climate signal across the Early Holocene climate events. Masson-Delmotte et al. (2005) used a model and both $\delta^{18} \mathrm{O}$ and deuterium excess data from GRIP and NGRIP to convert the isotope signals of the 8.2 ka event into site and source temperature anomalies, and found significant differences between the NGRIP and GRIP signals. Because well-calibrated deuterium excess data from the DYE-3 core are not available, and because the aim of this work is to present a mean regional signal rather than discussing differences between the individual Greenland ice cores, we refrain from converting the $\delta^{18} \mathrm{O}$ anomaly into a temperature anomaly. Instead we have made a simple mean of the 5 -year average $\delta^{18} \mathrm{O}$ profiles from the three cores, as we do not expect features on shorter time scales to represent a regional climate signal. These profiles are shown in Fig. 4, presented as anomalies from the average values in the 100 year periods before and after each of the four events.

With regard to the accumulation signals, we have applied the model of Andersen et al. (2006) to extract a common accumulation signal across each of the Early Holocene climate events. The model aims at constructing a common accumulation signal from the three individual records by maximizing the signal-to-residual ratio (analogous to the signal-to-noise ratio). In this context, "signal" is the common regional accumulation signal and "residual" is everything else, including local climate phenomena, depositional noise, and measurement noise. The analysis has been 


\begin{tabular}{lcccc}
\hline \hline Period & $8085-8415 \mathrm{~b} 2 \mathrm{k}$ & $9125-9455 \mathrm{~b} 2 \mathrm{k}$ & $9820-10150 \mathrm{~b} 2 \mathrm{k}$ & $11255-11585 \mathrm{~b} 2 \mathrm{k}$ \\
\hline DYE-3 & $1.33 \pm 0.02$ & $1.23 \pm 0.08$ & $1.08 \pm 0.05$ & $1.50 \pm 0.11$ \\
GRIP & $1.83 \pm 0.18$ & $1.73 \pm 0.19$ & $1.29 \pm 0.22$ & $2.02 \pm 0.27$ \\
NGRIP & $1.24 \pm 0.03$ & $1.33 \pm 0.04$ & $1.16 \pm 0.09$ & $3.11 \pm 0.50$ \\
\hline Model & $2.39 \pm 0.21$ & $2.29 \pm 0.28$ & $1.52 \pm 0.36$ & $4.63 \pm 0.62$ \\
\hline \hline
\end{tabular}

Table 1

Signal-to-residual ratios for the individual records and the modelled common accumulation signals for the four sections shown in Fig. 4. It should be noted that the error intervals represent the uncertainty intrinsic to the accumulation model only, and do not include the uncertainty in the individual accumulation profiles.

performed on 5-year average values to reduce the spectrally blue noise found in accumulation data (Fisher et al., 1985). The 5-year average values were formed from logarithmical transformed data as Rasmussen et al. (2006) found the annual layer thicknesses to be roughly log-normally distributed. Strain correction has not been performed prior to the analysis, as the model is insensitive to scaling of the accumulation series. The difference between the strain correction that should be applied to the top and bottom of each of the sections, respectively, can be evaluated using a simple strain model (e.g. Rasmussen et al., 2006). The difference is $1-3 \%$ for the different sections and is considered negligible.

The modelled accumulation series across the 8.2 ka event, the 9.3 ka event, the $9.95 \mathrm{ka}$ anomaly, and the Preboreal oscillation are shown in Fig. 4. The profiles are scaled so that the mean value over each interval is unity. The shaded envelopes around the accumulation model curves represent the uncertainty intrinsic to the model as described by Andersen et al. (2006) and does not take into account noise on the three original accumulation series or other factors contributing to the total uncertainty.

The signal-to-residual ratios of the individual records and the extracted common signal can be found in Table 1, which shows that a significant improvement of the signal-to-residual ratio is achieved. For the 8.5, 8.8, and $11.1 \mathrm{ka} \mathrm{b} 2 \mathrm{k} \delta^{18} \mathrm{O}$ anomalies, no significant accumulation anomalies are present in either the three individual accumulation records, or in the results of the accumulation model.

\subsection{The 8.2 ka event}

The 8.2 ka event stands out clearly in both the $\delta^{18} \mathrm{O}$ and accumulation signals with an amplitude of 1-2 permil and 10\%, respectively (Fig. 4a). The onset of the event is not well-defined, but is marked by a gradual decline in both $\delta^{18} \mathrm{O}$ and accumulation anomalies starting around $8300 \mathrm{~b} 2 \mathrm{k}$. The end of the event is somewhat better defined around $8140 \mathrm{~b} 2 \mathrm{k}$, which gives a duration of $160 \pm 10$ years, which is in line with a recent estimate of Thomas et al. (2007). While most of the decadal oscillations in 
the $\delta^{18} \mathrm{O}$ curve synchronize rather well with those of the accumulation curve, the short period of very low $\delta^{18} \mathrm{O}$ values around $8240-8245 \mathrm{ka} \mathrm{b} 2 \mathrm{k}$, that arises from a period of extremely low GRIP $\delta^{18} \mathrm{O}$ values (Thomas et al., 2007), is not reflected in the accumulation signal at all.

\subsection{The 9.3 ka event}

Although the general appearance of the $9.3 \mathrm{ka}$ event resembles that of the $8.2 \mathrm{ka}$ event, there is a greater disagreement between the accumulation and $\delta^{18} \mathrm{O}$ signals over the shape of the $9.3 \mathrm{ka}$ event (Fig. 4b). The onset can be defined as $9350 \mathrm{~b} 2 \mathrm{k}$ or $9310 \mathrm{~b} 2 \mathrm{k}$ from the $\delta^{18} \mathrm{O}$, and the central part of the $\delta^{18} \mathrm{O}$ minimum is about 40 year long, while the period of low accumulation values has a duration of about 70 years. The amplitude of both the $\delta^{18} \mathrm{O}$ and accumulation anomalies are similar to those of the $8.2 \mathrm{ka}$ event, and after the synchronous period of low values, both the $\delta^{18} \mathrm{O}$ and accumulation values rise gently over a 100-150 year long period. This contrasts with the sharp 2-step return to normal $\delta^{18} \mathrm{O}$ values observed at the end of the 8.2 ka event. The end of the $9.3 \mathrm{ka}$ event is therefore hard to define, and the overall duration of the $9.3 \mathrm{ka}$ event varies from 40 to more than 100 years depending on which criteria and which data series are used to define the onset and end.

\subsection{The 9.95 ka anomaly}

The $9.95 \mathrm{ka} \delta^{18} \mathrm{O}$ anomaly and the corresponding accumulation model results are shown in Fig. 4c. The $\delta^{18} \mathrm{O}$ anomaly of $9940-9950 \mathrm{~b} 2 \mathrm{k}$ has no counterpart in the accumulation signal, but instead a clear accumulation anomaly is observed more than 100 years earlier, centered around $10070 \mathrm{~b} 2 \mathrm{k}$. If the accumulation and $\delta^{18} \mathrm{O}$ signals had been obtained from independent archives, or even from independently dated ice cores, one could have made the error of assuming synchronicity between these accumulation and $\delta^{18} \mathrm{O}$ anomalies. This clearly illustrates the importance of good dating precision and underlines the dangers of wiggle-matching, when there is no independent evidence to suggest that the signals represent synchronous events.

\subsection{The Preboreal Oscillation}

The Preboreal oscillation stands out clearly in both $\delta^{18} \mathrm{O}$ and accumulation signals (Fig. 4d). The reference levels of the $\delta^{18} \mathrm{O}$ and accumulation curves (dashed lines) are not well-established in this time interval due the absence of stable climatic conditions prior to the Preboreal Oscillation, but from Figs. 2 and $4 \mathrm{~d}$ it is seen that the Preboreal oscillation consists of a short period of relatively high $\delta^{18} \mathrm{O}$ values starting within the first 50 years after the termination of GS-1 followed by a period 
of low $\delta^{18} \mathrm{O}$ values and low accumulation rates lasting for approximately 100 years, and ending with a period of moderate $\delta^{18} \mathrm{O}$ values and relatively high accumulation rates. In the central part from 11.5 to $11.4 \mathrm{ka} \mathrm{b} 2 \mathrm{k}$, the $\delta^{18} \mathrm{O}$ values are lowered by about 2 permil and the accumulation is reduced by $10-15 \%$. The oscillation ends with a short period of very high $\delta^{18} \mathrm{O}$ values around $11270-11280 \mathrm{~b} 2 \mathrm{k}$, about 400 years after the termination of GS-1.

\section{Conclusions}

We have presented synchronized $\delta^{18} \mathrm{O}$ records from the DYE-3, GRIP, and NGRIP ice cores covering the Early Holocene on the GICC05 time scale. The new time scale dates the 8.2 ka event with an estimated maximum counting error of 47 years, the $9.3 \mathrm{ka}$ event with an estimated maximum counting error of 70 years, and the Preboreal oscillation with an estimated maximum counting error of 97 years.

A comparison of the records across the $8.2 \mathrm{ka}$ event shows that the profiles agree on the approximate duration and amplitude of the anomaly, but the differences between the three profiles indicate that the individual Greenland ice core records should not be regarded as a regional, let alone hemispherical, signal on time scales much shorter than 5-10 years. When correlating data from other archives with the Greenland ice core records it is essential to consider whether there is a reason for comparing with one specific ice core. Rogers et al. (2002) found that different ice cores that were retrieved from sites relatively close to each other but from East and West sides of the ice divide, respectively, recorded either Greenland East or West coast climate. In the same way the DYE-3 site may be much more influenced by storm tracks passing the Southern tip of Greenland than GRIP and NGRIP (Hutterli et al., 2005), and hence the DYE-3 climate record is thus the obvious choice for comparison with data from other climate archives in the South Greenland area. On the other hand, if no such preference can be assumed, and data from no specific ice core are preferable a priori, we propose that the common accumulation and isotope signals presented here are used as a representation of regional Greenland climate variability.

As illustrated in Figs. 2 and 4, the 8.2 ka event, the 9.3 ka event and the Preboreal oscillation have distinct $\delta^{18} \mathrm{O}$ and accumulation anomalies, and these events are the only events in the $7.9-11.7 \mathrm{ka} \mathrm{b} 2 \mathrm{k}$ interval that have significant synchronous $\delta^{18} \mathrm{O}$ and accumulation anomalies that are common to the three cores. The central part of the events include a 1-2 permil lowering of the $\delta^{18} \mathrm{O}$ value, corresponding to several degrees of cooling if the $\delta^{18} \mathrm{O}$ anomaly is interpreted as a temperature signal, which agrees fairly well with the temperature reconstruction of the $8.2 \mathrm{ka}$ event by Masson-Delmotte et al. (2005). The mean annual accumulation is about $10-15 \%$ below the normal level during each of the events, but the relative timing of the $\delta^{18} \mathrm{O}$ minima and the accumulation anomalies is not the same for the three events, and there seems to be no general connection between the the deepest $\delta^{18} \mathrm{O}$ and accumulation minima, confirming that in the Holocene on short time scales 
other parameters than temperature are important in governing how much snowfall central Greenland receives (Crüger et al., 2004; Andersen et al., 2006).

\section{Data access}

The construction of the GICC05 time scale in the Holocene is described in Vinther et al. (2006) and Rasmussen et al. (2006). The DYE-3, GRIP, and NGRIP $\delta^{18} \mathrm{O}$ profiles are available on the GICC05 time scale at http://icecores.dk together with the $\delta^{18} \mathrm{O}$ and accumulation model anomaly results presented in Fig. 4. Future extensions of the GICC time scale will also be posted here.

\section{Acknowledgements}

This work is a contribution of the Copenhagen Ice Core Dating Initiative which is supported by a grant from the Carlsberg Foundation.

NGRIP is directed and organized by the Ice and Climate Research Group at the Niels Bohr Institute, University of Copenhagen, Denmark. It is supported by funding agencies in Denmark (SNF), Belgium (FNRS-CFB), France (IPEV and INSU/CNRS), Germany (AWI), Iceland (RannIs), Japan (MEXT), Sweden (SPRS), Switzerland (SNF) and the USA (NSF, Office of Polar Programs).

\section{References}

Alley, R., Ágústdóttir, A., 2005. The 8k event: cause and consequences of a major Holocene abrupt climate change. Quaternary Science Reviews 24, 1123-1149.

Alley, R., Mayewski, P., Sowers, T., Stuiver, M., Taylor, K., Clark, P., 1997a. Holocene climatic instability: A prominent widespread event 8200 yr ago. Geology 25, 483-486.

Alley, R. B., Shuman, C. A., Meese, D. A., Gow, A. J., Taylor, K. C., Cuffey, K. M., Fitzpatrick, J. J., Grootes, P. M., Zielinski, G. A., Ram, M., Spinelli, G., Elder, B., 1997b. Visual-stratigraphic dating of the GISP2 ice core: Basic, reproducibility, and application. Journal of Geophysical Research 102 (C12), 26367-26381.

Andersen, K. K., Ditlevsen, P. D., Rasmussen, S. O., Clausen, H. B., Johnsen, S. J., Steffensen, J. P., 2006. Retrieving a common accumulation record from Greenland ice cores for the past 1800 years. Journal of Geophysical Research 111, D15106.

Barber, D., Dyke, A., Hillaire-Marcel, C., Jennings, A., Andrews, J., Kerwin, M., Bilodeau, G., McNeely, R., Southon, J., Morehead, M., Gagnon, J.-M., 1999. Forcing of the cold event of 8,200 years ago by catastrophic drainage of Laurentide lakes. Nature 400, 344-348. 
Bard, E., Arnold, M., Mangerud, M., Paterne, M., Labeyrie, L., Duprat, J., Mélières, M. A., Sonstegaard, E., Duplessy, J. C., 1994. The North Atlantic atmospheresea surface ${ }^{14} \mathrm{C}$ gradient during the Younger Dryas climatic event. Earth and Planetary Science Letters 126, 275-287.

Bigler, M., 2004. Hochauflösende Spurenstoffmessungen an polaren Eisbohrkernen: Glaziochemische und klimatische Prozessstudien, Ph.D. dissertation, University of Bern, Switzerland.

Birks, H., Gulliksen, S., Haflidason, H., Mangerud, J., Possnert, G., 1996. New radiocarbon dates for the Vedde Ash and the Saksunarvatn Ash from Western Norway. Quaternary Research 45 (2), 119-127.

Björck, S., Ingólfsson, Ó., Haflidason, H., Hallsdóttir, M., Andersson, N. J., 1992. Lake Torfadalsvatn: a high resolution record of the North Atlantic ash zone I and the last glacial-interglacial environmental changes in Iceland. Boreas 21, 15-22.

Björck, S., Muscheler, R., Kromer, B., Andresen, C., Heinemeier, J., Johnsen, S., Conley, D., Koç, N., Spurk, M., Veski, S., 2001. High-resolution analyses of an early Holocene climate event may imply decreased solar forcing as an important climate trigger. Geology 12, 1107-1110.

Björck, S., Rundgren, M., Ingólfsson, Ó., Funder, S., 1997. The Preboreal oscillation around the Nordic Seas: terrestrial and lacustrine responses. Journal of Quaternary Science 12, 455-465.

Bond, G., Showers, W., Cheseby, M., Lotti, R., Almasi, P., deMenocal, P., Priore, P., Cullen, H., Hajdas, I., Bonani, G., 1997. A pervasive millennial-scale cycle in North Atlantic Holocene and glacial climates. Science 278 (5341), 1257-1266.

Crüger, T., Fischer, H., von Storch, H., 2004. What do accumulation records of single ice cores in Greenland represent? Journal of Geophysical Research 109, D21110.

Dansgaard, W., Clausen, H., Gundestrup, N., Hammer, C., Johnsen, S., Kristinsdottir, P., Reeh, N., 1982. A new Greenland deep ice core. Science 218, 1273-1277.

Fisher, D. A., Reeh, N., Clausen, H. B., 1985. Stratigraphic noise in time series derived from ice cores. Annals of Glaciology 7, 76-83.

Fuhrer, K., Neftel, A., Anklin, M., Maggi, V., 1993. Continuous measurements of hydrogen peroxide, formaldehyde, calcium and ammonium concentrations along the new GRIP ice core from Summit, Central Greenland. Atmospheric Environment 27A (12), 1873-1880.

Fuhrer, K., Neftel, A., Anklin, M., Staffelbach, T., Legrand, M., 1996. Highresolution ammonium ice core record covering a complete glacial-interglacial cycle. Journal of Geophysical Research 101 (D2), 4147-4164.

Grönvold, K., Óskarsson, N., Johnsen, S. J., Clausen, H. B., Hammer, C. U., Bond, G., Bard, E., 1995. Ash layers from Iceland in the Greenland GRIP ice core correlated with oceanic and land sediments. Earth and Planetary Science Letters 135, 149-155.

Hammer, C. U., Clausen, H. B., Tauber, H., 1986. Ice-core dating of the Pleistocene/Holocene boundary applied to a calibration of the ${ }^{14} \mathrm{C}$ time scale. Radiocarbon 28, 284-291.

Hutterli, M. A., Raible, C. C., Stocker, T. F., 2005. Reconstructing climate vari- 
ability from Greenland ice sheet accumulation: An ERA40 study. Geophysical Research Letters 32, L23712.

Jóhansen, J., 1975. Pollen diagrams from the Shetland and Faroe Islands. New Phytologist 75, 369-387.

Johnsen, S. J., Clausen, H. B., Dansgaard, W., Gundestrup, N. S., Hammer, C. U., Andersen, U., Andersen, K. K., Hvidberg, C. S., Dahl-Jensen, D., Steffensen, J. P., Shoji, H., Sveinbjörnsdóttir, Á. E., White, J., Jouzel, J., Fisher, D., 1997. The $\delta^{18} \mathrm{O}$ record along the Greenland Ice Core Project deep ice core and the problem of possible Eemian climatic instability. Journal of Geophysical Research 102 (C12), 26397-26410.

Johnsen, S. J., Dahl-Jensen, D., Gundestrup, N., Steffensen, J. P., Clausen, H. B., Miller, H., Masson-Delmotte, V., Sveinbjörnsdottir, A. E., White, J., 2001. Oxygen isotope and palaeotemperature records from six Greenland ice-core stations: Camp Century, Dye-3, GRIP, GISP2, Renland and NorthGRIP. Journal of Quaternary Science 16, 299-307.

Johnsen, S. J., Dansgaard, W., White, J., 1989. The origin of Arctic precipitation under present and glacial conditions. Tellus 41B, 452-468.

Masson-Delmotte, V., Landais, A., Stievenard, M., Cattani, O., Falourd, S., Jouzel, J., Johnsen, S. J., Dahl-Jensen, D., Sveinsbjornsdottir, A., White, J. W. C., Popp, T., Fischer, H., 2005. Holocene climatic changes in Greenland: Different deuterium excess signals at Greenland Ice Core Project (GRIP) and NorthGRIP. Journal of Geophysical Research 110, D14102.

McDermott, F., Mattey, D. P., Hawkesworth, C., 2001. Centennial-scale Holocene climate variability revealed by a high-resolution speleothem $\delta^{18} \mathrm{O}$ record from SW Ireland. Science 294 (5545), 1328-1331.

Meese, D. A., Gow, A. J., Alley, R. B., Zielinski, G. A., Grootes, P. M., Ram, M., Taylor, K. C., Mayewski, P. A., Bolzan, J. F., 1997. The Greenland Ice Sheet Project 2 depth-age scale: Methods and results. Journal of Geophysical Research 102 (C12), 26411-26423.

NGRIP members, 2004. High-resolution record of Northern Hemisphere climate extending into the last interglacial period. Nature 431, 147-151.

Rasmussen, S. O., Andersen, K. K., Svensson, A. M., Steffensen, J. P., Vinther, B., Clausen, H. B., Siggaard-Andersen, M.-L., Johnsen, S. J., Larsen, L. B., DahlJensen, D., Bigler, M., Röthlisberger, R., Fischer, H., Goto-Azuma, K., Hansson, M., Ruth, U., 2006. A new Greenland ice core chronology for the last glacial termination. Journal of Geophysical Research 111, D06102.

Reimer, P. J., Baillie, M. G. L., Bard, E., Bayliss, A., Beck, J. W., Bertrand, C. J. H., Blackwell, P. G., Buck, C. E., Burr, G. S., Cutler, K. B., Damon, P. E., Edwards, R. L., Fairbanks, R. G., Friedrich, M., Guilderson, T. P., Hogg, A. G., Hughen, K. A., Kromer, B., McCormac, G., Manning, S., Ramsey, C. B., Reimer, R. W., Remmele, S., Southon, J. R., Stuiver, M., Talamo, S., Taylor, F. W., van der Plicht, J., Weyhenmeyer, C. E., 2004. Radiocarbon calibration from 0-26 cal kyr BP. Radiocarbon 46 (3), 1029-1058.

Renssen, H., Goosse, H., Fichefet, T., Campin, J.-M., 2001. The 8.2 kyr BP event simulated by a global atmosphere-sea-ice-ocean model. Geophysical Research Let- 
ters 28, 1567-1570.

Rogers, J. C., Bolzan, J. F., Pohjola, V. A., 2002. Atmospheric circulation variability associated with shallow-core seasonal isotopic extremes near Summit, Greenland. Journal of Geophysical Research D10, 11,205-11,219.

Rohling, E., Pälike, H., 2005. Centennial-scale climate cooling with a sudden cold event around 8,200 years ago. Nature 434, 975-979.

Röthlisberger, R., Bigler, M., Hutterli, M., Sommer, S., Stauffer, B., Junghans, H., Wagenbach, D., 2000. Technique for continuous high-resolution analysis of trace substances in firn and ice cores. Environmental Science and Technology 34 (2), 338-342.

Thomas, E., Wolff, E., Mulvaney, R., Steffensen, J., Johnsen, S., Arrowsmith, C., White, J., Vaughn, B., Popp, T., 2007. The 8.2 kyr event from Greenland ice cores. Quaternary Science Reviews 26 (1-2), 70-81.

Vinther, B. M., Clausen, H. B., Johnsen, S. J., Rasmussen, S. O., Andersen, K. K., Buchardt, S. L., Dahl-Jensen, D., Seierstad, I. K., Siggaard-Andersen, M.-L., Steffensen, J. P., Svensson, A. M., Olsen, J., Heinemeier, J., 2006. A synchronized dating of three Greenland ice cores throughout the Holocene. Journal of Geophysical Research 111, D13102.

von Grafenstein, U., Erlenkeuser, H., Brauer, A., Jouzel, J., Johnsen, S. J., 1999. A Mid-European decadal isotope-climate record from 15,500 to 5000 years B.P. Science 284 (5420), 1654-1657.

Wastegård, S., Björck, S., Possnert, G., Wohlfarth, B., 1998. Evidence for the occurrence of Vedde Ash in Sweden: radiocarbon and calendar age estimates. Journal of Quaternary Science 13, 271-274.

Wiersma, A., Renssen, H., 2006. Model-data comparison for the 8.2 ka BP event: Confirmation of a forcing mechanism by catastrophic drainage of Laurentide Lakes. Quaternary Science Reviews 25 (1-2), 63-88. 